Journal of Animal and Veterinary Advances 10 (11): 1421-1426, 2011

ISSN: $1680-5593$

(C) Medwell Journals, 2011

\title{
Detection of sef14, sef17 and sef21 Fimbrial Virulence Genes of Salmonella enteritidis by Multiplex PCR
}

\author{
T. Zahraei Salehi, O. Madadgar, S. Naserli, B. Nayeri Fasaei, \\ M.M. Ghafari and I. Ashrafi Tamai \\ Department of Microbiology, Faculty of Veterinary Medicine, \\ University of Tehran, Tehran, Iran
}

\begin{abstract}
Salmonella serovars show their diverse effects by joining the gastrointestinal epithelia. The infectious trait of this bacterium depends on colonization in GI epithelial surfaces. Fimbirae play the main role in this junction. Three kinds of fimbrial genes are more important and responsible for the pathogenecity and the attachment of Salmonella enteritidis to intestinal epithelium (sef14, 17, 21). Therefore, researchers have attempted to study the significance of fimbriae genes by the molecular method. In first of all, the molecular method has to be optimized for investigating the presence of these genes in the confirmed isolates of $S$. enteritidis. About 45 isolates of $S$. enteritidis collected from 60 diarrheic feces of both livestock and avian population with clinical sign of diarrhea were considered. In order to trace the most important fimbrial genes, the multiplex PCR method was designed and optimized. The optimal primers, annealing temperature of primers and concentration of DNA template, $\mathrm{MgCl}_{2}$ and Taq DNA polymerase were determined.
\end{abstract}

Key words: $S$. enteritidis, sef14, sef1 7, sef21, Multiplex PCR, Iran

\section{INTRODUCTION}

Salmonella enterica serovar Enteritidis is the main cause of food-borne salmonellosis (Collighan and Woodward, 2001) and during the last 20 years, it has been a major causative agent of food-borne gastroenteritis in humans (Oliveira et al., 2003; Clayton et al., 2008; Mirmomeni et al., 2008). There is increasing evidence suggesting that the main sources of human pathogens are poultry products especially eggs (Pasmans et al., 2005; Gantois et al., 2008). Salmonella serovars have been found on the mucosal surface and within epithelial cells, lining the oviduct in naturally and experimentally infected hens. Some virulence factors have been identified as playing key roles in the infection (Gantois et al., 2008). One strategy utilized by bacterial pathogens to colonize host cell surfaces involves bacterial adhesive appendages called fimbriae which bind glycoprotein or glycolipid receptors on epithelial cells (Clayton et al., 2008). Fimbriae of nontyphoid Salmonella sp. are apparently adhesive organelles possibly required for adherence and colonization to intestinal epithelial cells by these enteropathogens in the initial stages of gastroenteritis (Collinson et al., 1993). Fimbriae are primarily composed of polymerized fimbrilin protein monomers and in some cases have been shown to bind eukaryotic cell surfaces directly or via fimbria-associated adhesin proteins (Darwin and Miller, 1999; Humphries et al., 2001; Naughton et al., 2001b). It is generally accepted that fimbriae are an important factor in bacterial survival and persistence in the host (Clayton et al., 2008). They are involved in the adhesion of bacteria to different cells surfaces that is often the initial step in the colonization to host tissue and an essential stage in pathogenesis of salmonellosis.

Salmonella enteritidis fimbriae sef14, sef17 and sef21 are composed of major fimbrial proteins (Thorns et al., 1996). In Salmonella enteritidis the sef operon encodes for Salmonella enteritidis fimbriae-like structure (sefl 4 fimbriae) (Murugkar et al., 2003; Van Asten and van Dijk, 2005). Sefl 4 has been shown to be a T-cell immunogen and contribute to adherence to mouse epithelial cells (Naughton et al., 2001b). Sefl 4 fimbriae are only found in Salmonella enterica serovar enteritidis (S. enteritidis) and closely related serovars suggesting that sefl 4 fimbriae may affect serovar-specific virulence traits (Edwards et al., 2000; Collighan and Woodward, 2001).

Also, fimbriae encoded by the agf operon are designated sef1 7 fimbriae or thin aggregative fimbriae (Tafi) (Collinson et al., 1999) and sef21 are composed of $21 \mathrm{kDa}$ fimbrin monomers that are virtually identical to the type 1 fimbrin of $S$. enteritidis (Thorns et al., 1996; Naughton et al., 2001b).

Corresponding Author: Omid Madadgar, Department of Microbiology, Faculty of Veterinary Medicine, University of Tehran, P.O. Box 14155-6453, Tehran, Iran 
Salmonella serovars is routinely detected in clinical, food and environmental samples using microbiological culture after enrichment step and should be then serotyped (Del Cerro et al., 2003). Currently the most common method of typing of $S$. enterica subsp. enterica has been to discriminate isolates on the basis of $O$ (surface polysaccharide) and $\mathrm{H}$ (flagellar) antigenic properties. Typing the $O$ antigen denotes the serogroup and typing the flagellae denotes the serotype (Herrera-Leon et al., 2004). The scoring of antigenic formulae uses the Kaufmann-White scheme which is annually updated. Despite its widespread use, serotyping has deficiencies that limit its utility including that it often takes 3 or more days to generate a result (Soumet et al., 1999). While PCR and various PCR based technologies provide fast results and a high degree of specificity and constitute a valuable tool in microbiological diagnostics (Soumet et al., 1999; Oliveira et al., 2003). The multiplexPCR is one of these methods which gives best results with a number of positive results similar to those obtained by bacteriological method and reduce the time needed to detect Salmonella (Naughton et al., 2001a). As the first step of investigating the simultaneous presence of these three fimbrial genes, the multiplex PCR was designed and optimized to detect sef14, sefl 7 and sef21 genes in $S$. enteritidis and define its exact role in pathogenecity. To indicate the role of fimbrial genes in $S$. enteritidis, samples of two groups were compared a group with clinical signs and an other group without any clinical signs related to salmonellosis. Thus $45 \mathrm{~S}$. enteritidis bacteria isolated from fecal samples with diarrhea (from livestock and poultry) were considered for analyzing the presence of the three desired genes. Then the results of $45 \mathrm{~S}$. enteritidis bacteria isolated from diarrheic samples and $25 \mathrm{~S}$. enteritidis isolated from avian non diarrheic samples were compared. In order to achieve this, firstly $S$. enteritidis were isolated by the standard methods and serovar of Salmonella isolated were detected by valid antisera using serotyping protocol (Kaufmann-White scheme). Then the detected serovar of Salmonella isolates were confirmed by multiplex PCR. We also optimized an accurate program to obtain similar and uniform bands with different primers.

\section{MATERIALS AND METHODS}

Samples: About 60 diarrheic feces of patient with salmonellosis signs, 30 of which were collected from hens and thirty others from livestock from different regions were sent to microbiology laboratory and were considered for the isolation of Salmonella. The samples were collected in the sterile containers and transferred under cold conditions (with ice pack) to the lab. Also, 25 $S$. enteritidis bacteria from the collection of the Microbiology Department, Faculty of Veterinary Medicine, University of Tehran, previously isolated from hen non diarrheic feces were chosen for a comparative study.

Bacterial growth: The samples were immediately cultured in the selenite $\mathrm{F}$ (Merck) at $37^{\circ} \mathrm{C}$ for $18 \mathrm{~h}$ as enrichment media then the samples were transferred on to $\mathrm{Mc}$ Conckey and SS (Salmonella and Shigella) agar (Merck) at $37^{\circ} \mathrm{C}$ overnight for isolation. Every suspected Salmonella colony was considered for serotyping. After Salmonella isolation, the isolates were cultured in $\mathrm{BHI}$ (brain heart infusion broth, Merck) at $37^{\circ} \mathrm{C}$ overnight and retransferred to Luria Bertani agar (LB, Merck). After overnight incubation, Salmonella colonies were observed.

Conventional serotyping confirmed by multiplex PCR: The isolation of Salmonella were analyzed for serotyping by $\mathrm{O}$ and $\mathrm{H}$ antisera (Difco, Detroit, USA) and then confirmed via multiplex PCR. According to Pan and Liu (2002), method three pairs of primers were used to detect sef A, spv and Random sequence to confirm $S$. enteritidis. Target genes and primers is shown in Table 1 .

Multiplex-PCR used for detection of sef14, sef17 and sef21: The multiplex PCR was designed by three pairs of primers selected from last studies (Sukhnanand et al., 2005; Pasmans et al., 2005; Cortez et al., 2008) and was performed on the $S$. enteritidis isolates for the detection of sefl 4, sef1 7 and sef 21 genes. The selected primers and target genes are shown in Table 2.

A single colony of each isolate on agar plate was picked up and suspended in $200 \mu \mathrm{L}$ of distilled $\mathrm{H}_{2} \mathrm{O}$. After vortexing, the suspension was boiled for $10 \mathrm{~min}$ and $50 \mu \mathrm{L}$ of the supernatant was collected after centrifugating for $10 \mathrm{~min}$ at $14,000 \mathrm{rpm}$ in a microcentrifuge. The DNA concentration of boiled extracts was determined with a spectrophotometer (Madadgar et al., 2008).

Table 1: Nucleotide sequences used as primers in the multiplex PCR for confirmation of S. enteritidis

\begin{tabular}{|c|c|c|c|}
\hline$\underline{\text { Primer }}$ & $\begin{array}{l}\text { Target } \\
\text { gene }\end{array}$ & Sequence & $\begin{array}{l}\text { Amplified } \\
\text { fragment } \\
\text { size (bp) } \\
\end{array}$ \\
\hline ST11 & $\begin{array}{l}\text { Random } \\
\text { sequence }\end{array}$ & 5'GCCAACCATTGCTAAATTGGCGCA & 429 \\
\hline ST14 & & 5'GGTAGAAATTCCCAGCGGGTACTGG & \\
\hline S1 & $\mathrm{spv}^{\mathrm{b}}$ & 5'GCCGTACACGAGCTTATAGA & 250 \\
\hline S4 & & 5'ACCTACAGGGGCACAATAAC & \\
\hline SEF A2 & $\operatorname{sef}^{c}$ & 5'GCAGCGGTTACTATTGCAGC & 310 \\
\hline SEF A4 & & 5'TGTGACAGGGACATTTAGCG & \\
\hline
\end{tabular}


Table 2: Nucleotide sequence of primers used to determine the presence of virulence genes in Salmonella isolates

\begin{tabular}{|c|c|c|c|c|}
\hline Primer & $\begin{array}{c}\text { Target } \\
\text { gene }\end{array}$ & Sequence & $\begin{array}{c}\text { Amplified } \\
\text { fragment } \\
\text { size (bp) }\end{array}$ & $\begin{array}{l}\text { Ref. } \\
\text { No }\end{array}$ \\
\hline SEF $14 \mathrm{R}$ & sef $A$ & 5'TGTGACAGGGACATTTAGCG & 330 & 7 \\
\hline SEF $14 \mathrm{~F}$ & & 5'GCAGCGGTTACTATTGCAGG & & \\
\hline SEF $17 \mathrm{R}$ & $\operatorname{agf} \mathrm{A}$ & 5ACCAACCTGACGCACCATTA & 400 & 26 \\
\hline SEF $17 \mathrm{~F}$ & & 5'GCATTCGCAATCGTAGT & & \\
\hline SEF $21 \mathrm{R}$ & fim A & 5'TCCCCGATAGCCTCTTCC' & 750 & 28 \\
\hline SEF $21 \mathrm{~F}$ & & 5TCAGGGGAGAAAACTAAT & & \\
\hline
\end{tabular}

PCR was conducted in a $25 \mu \mathrm{L}$ volume containing $80 \mathrm{ng}$ of total DNA, $1.5 \mathrm{mMMgCl}_{2}, 0.5 \mu \mathrm{M}$ of primers, $2 \mathrm{U}$ of Taq DNA polymerase and $200 \mathrm{mM}$ dNTPs mix in $1 \mathrm{X}$ PCR buffer (Fermentas, Latvia).

The PCR was performed by thermocycler (Techne, UK) initiated by denaturation at $94^{\circ} \mathrm{C}$ for 1 min followed by 35 cycles of amplification consisting of denaturation at $94^{\circ} \mathrm{C}$ for $30 \mathrm{sec}$, annealing at $56^{\circ} \mathrm{C}$ for $90 \mathrm{sec}$ and extension at $72^{\circ} \mathrm{C}$ for $30 \mathrm{sec}$ and the final extension at $72^{\circ} \mathrm{C}$ for $10 \mathrm{~min}$. The amplified products were electrophoresed on a $1.5 \%$ agarose gel stained with ethidium bromide and visualized under ultraviolet light.

Optimization of M-PCR used for detection of sef14, sef17 and sef21: Multiplex-PCR for the detection of sefl 4, sefl 7 and sef21 was first optimized. Optimal annealing temperature of primers and concentration of DNA template, $\mathrm{MgCl}_{2}$ and Taq DNA polymerase were determined. The suitable primers applied for the detection of sefl 4, sefl 7 and sef21 had been reported by Cortez et al. (2008), Pasmans et al. (2005) and Sukhnanand et al. (2005), respectively.

\section{RESULTS}

Results of serotyping and M-PCR for detection of $S$. enteritidis: Of 60 feces collected from patients with salmonellosis signs, the isolated from 48 samples were agglutinated with group D antiserum. About 45 out of those 48 isolates were determined as $S$. enteritidis in serotyping presenting antigenic formula of $(1,9,12: \mathrm{g}, \mathrm{m})$ and 250, 310 and 429 bp identical bands which indicated spv, sef A, Random sequence, respectively in the multiplex PCR and confirmed as $S$. enteritidis (Pan and Liu, 2002). Also, all the $25 \mathrm{~S}$. enteritidis of avian source determined by conventional serotyping were confirmed by multiplex PCR. M-PCR results of some isolates of S. enteritidis are shown in Fig. 1.

Results of multiplex-PCR for the detection of sef14, sef17 and sef21: All the 45 Salmonella enteritidis isolated from patients and 25 Salmonella enteritidis isolated from healthy chicken presented identical bands of 330,400 and 750 bp size which indicated sefl 4 , sefl 7

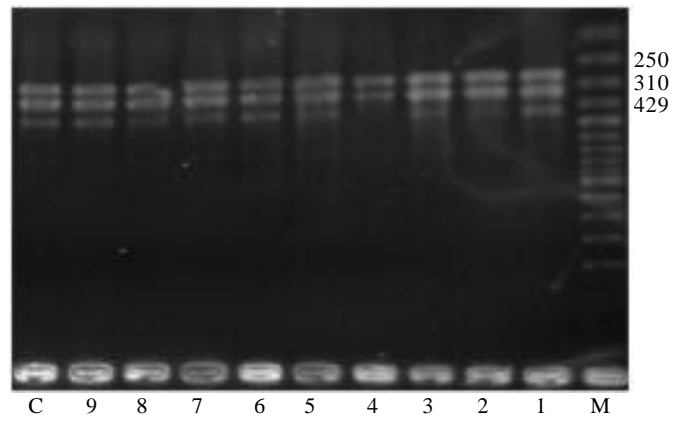

Fig. 1: M-PCR results of some isolates for detection of $S$. enteritidis. The bands are organized from lighter to heavier, inclusive Random sequence, sef $\mathrm{A}$ and spv which are located at range of $250,310,429 \mathrm{~kb}$ respectively. $\mathrm{M}$ presents $100 \mathrm{bp}$ marker (Fermentaz, Latvia) and C presents positive control (confirmed with reliable serotyping)

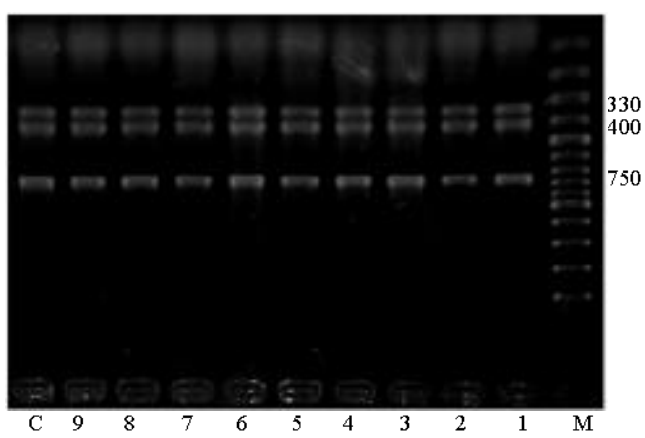

Fig. 2: M-PCR results of some isolates for detection of sef14, sef1 7 and sef21. The bands indicated to sef $\mathrm{A}, \operatorname{agf} \mathrm{A}$ and fimA which are located at range of $330,400,750 \mathrm{~kb}$ as sefl 4,17,21, respectively. $\mathrm{M}$ presents 100 bp marker (Fermentaz, Latvia) and C presents positive control (confirmed in the late gels)

Table 3: Results of comparison between M-PCR of samples with and without clinical sings

\begin{tabular}{llllll}
\hline No. of isolates & Source & Years & sefA & fimA & agfA \\
\hline Patient sample & & & & & \\
40 & Chicken & 2009 & + & + & + \\
3 & Sheep & 2009 & + & + & + \\
2 & Calf & 2009 & + & + & + \\
Healthy sample & & & & & \\
25 & Chicken & $2007-9$ & + & + & + \\
\hline
\end{tabular}

and sef21, respectively. So, all the isolates had three genes of sef $A$, agf $A, \operatorname{fim} A$ (Fig. 2). Results are briefly shown in Table 3.

Results of optimization of M-PCR used for detection of sef14, sef17 and sef21: To obtain the optimal concentration of arbitrary primer, 0.75 and $1 \mu \mathrm{M}$ 
concentrations were tested and $1 \mu \mathrm{M}$ was selected DNA template was tested at the concentrations of 40,60 and $80 \mathrm{ng}$ per reaction, among which the $80 \mathrm{ng}$ concentration was selected.

The optimal concentration of $\mathrm{MgCl}_{2}$ was obtained by testing the concentrations of $1,1.2$ and $1.5 \mathrm{mM}$ and $1.5 \mathrm{mM}$ was adequate. Taq DNA polymerase was tested at the amounts of $1,1.5$ and $2 \mathrm{U}$. The two unit concentration per reaction was found suitable. Finally, we found out $57^{\circ} \mathrm{C}$ was the best annealing temperature among the 53-60 different annealing temperatures (Fig. 2).

\section{DISCUSSION}

Contrary to many bacterial flora in digestive system which are opportunist such as $E$. coli and their pathogenesis depends on immune suppression, Salmonella is a real pathogen. Therefore, Salmonella pathogenesis in host tissue depends on virulent factors for colonization and penetration.

Many studies indicate the importance of $S$. enteritidis sef14, sef17, sef 21 genes as a connecting factor to the host tissues. According to the studies of Kisiela et al. (2003), Ochoa-Reparaz et al. (2004) and Mirmomeni et al. (2008) fimbriae are introduced as the most important survival and continuity factor for Salmonella enteritidis. Clegg et al. (1996), Collighan and Woodward (2001), Naughton et al. (2001a), Murugkar et al. (2003) and Clayton et al. (2008) declared that in spite of subsequent presence of fimbriae in Salmonella as virulent and colonization factor, it is not expected to obtain symptoms.

The study of fimbriae genes and simultaneous presence of these three fimbrial genes as the first step for defining its exact role in pathogenecity should be considered. As a result, the multiplex-PCR was designed and optimized for the detection of these genes.

The application of the approved oligonucleotides (as primers), existence of precise band sizes in $S$. enteritidis isolates and high quality of figures of M-PCR with equal intensity of three bands are reasons for validity of this multiplex-PCR method.

It seems that bacterial colonization and proliferation in intestinal tissue is necessary for resistance against fluid flow and flashing of fecal materials. According to these and the presence of the three important fimbrial genes in all isolates of this study, it could be concluded that the presence of the fimbrial genes is necessary and inevitable for pathogenesis and clinical signs but is not enough for those purposes. It seems that other virulent factors such as endotoxins, entrotoxins, resistance to phagocytosis and complement destruction, plasmid genes and flagella are necessary for the penetration and dissemination of S. enteritidis as real pathogen. Also, it seems that high expression level of these three fimbrial genes following the bacterial junction to surface of intestine, logically preserve Salmonella from fluid flow and prepares it for colonization and proliferation which is followed by activation of other virulent factors resulting in propagation of $S$. enteritidis. Finally, considering to the expression level of these virulent factors, the severity of involvement and complication could be different.

This study declared the importance level of the presence of fimbrial genes in the pathogenesis of $S$. enteritidis and presented the new M-PCR method for following these most important fimbrial genes of $S$. enteritidis in the various features of pathogenesis and determines the role of these genes in relation with other virulent factors in the future studies.

\section{CONCLUSION}

The results of comparative M-PCR on 45 isolates collected from patients and $25 \mathrm{~S}$. enteritidis isolates collected from avian feces without the clinical signs indicated the presence of three sefA (sef14), agfA (sef17) and fimA (sef21) fimbrial genes in all the isolates of $S$. enteritidis. So, the presence of fimbrial genes that is logically essential for colonization is not an enough reason for manifestation of clinical sings but both the genetic expression level and the collection of influences of virulent factors like fimbriae may be important for manifestation of clinical signs. This study demonstrated the level of importance of the fimbrial genes presence in the pathogenesis of $S$. enteritidis. In the meantime the new M-PCR method was presented in order to follow up the most important fimbrial genes in various features of pathogenesis. The relation of these genes with other virulent factors can also be studied in the future studies.

\section{ACKNOWLEDGEMENTS}

The researchers are grateful to the ministry of science, Research and Technology, Research Council of University of Tehran and Research Council of faculty of Veterinary Medicine for financial support of project no. 7504002/6/9. 


\section{REFERENCES}

Clayton, D.J., A.J. Bowen, S.D. Hulme, A.M. Buckley and V.L. Deacon et al., 2008. Analysis of the role of 13 major fimbrial subunits in colonisation of the chicken intestines by Salmonella enterica serovar Enteritidis reveals a role for a novel locus. BMC Microbiol., 8: 228-228.

Clegg, S., L.S. Hancox and K.S. Yeh, 1996. Salmonella typhimurium fimbrial phase variation and fimA expression. J. Bacteriol., 178: 542-545.

Collighan, R.J. and M.J. Woodward, 2001. The SEF14 fimbrial antigen of Salmonella enterica serovar Enteritidis is encoded within a pathogenicity islet. Vet. Microbiol., 80: 235-245.

Collinson, S.K., J.M.R. Parker, R.S. Hodges and W.W. Kay, 1999. Structural predictions of AgfA, the insoluble fimbrial subunit of Salmonella thin aggregative fimbriae. J. Mol. Bacteriol., 290: 741-756.

Collinson, S.K., P.C. Doig, J.L. Doran, S. Clouthier, L. T.J. Trust and W.W. Kay, 1993. Thin, aggregative fimbriae mediate binding of Salmonella entenitidis to fibronectin. J. Bacteriol., 175: 12-18.

Cortez, A.L.L., A.C.F.B. Carvalho, A.A. Ikuno, K.P. Burger and A.M.C. Vidal-Martins, 2008. Identification of Salmonella sp. isolates from chicken abattoirs by MPCR. Vet. Sci., 81: 340-344.

Darwin, K.H. and V.L. Miller, 1999. Molecular basis of the interaction of Salmonella with the intestinal mucosa. Clin. Microbiol. Rev., 12: 405-428.

Del Cerro, A., S.M. Soto and M.C. Mendoza, 2003. Virulence and antimicrobial-resistance gene profiles determined by PCR-based procedures for Salmonella isolated from samples of animal origin. Food Microbiol., 20: 431-438.

Edwards, R.A., D.M. Schifferli and S.R. Maloy, 2000. A role for Salmonella fimbriae in intraperitoneal infections. Proc. Nat. Acad. Sci. USA., 97: 1258-1262.

Gantois, I., R. Ducatelle, F. Pasmans, F. Haesebrouck and F. van Immerseel, 2008. Salmonella enterica serovar enteritidis genes induced during oviduct colonization and egg contamination in laying hens. Applied Environ. Microbiol., 74: 6616-6622.

Herrera-Leon, S., J.R. McQuiston, M.A. Usera, P.I. Fields, J. Garaizar and M.A. Echeita, 2004. Multiplex PCR for distinguishing the most common phase-1 Flagellar antigens of Salmonella sp. J. Clin. Microbiol., 42: 2581-2586.

Humphries, A.D., S.M. Townsend, R.A Kingsley, T.L. Nicholson, R.M. Tsolis and A.J. Baumler, 2001. Role of fimbriae as antigens and intestinal colonization factors of Salmonella serovars. FEMS Microbiol. Let., 201: 121-125.
Kisiela, D., M. Kuczkowski, A. Wieliczco, I. Sambor, M. Mazurkiewicz and M. Ugorski, 2003. Comparison of Sef A, FimA, Agf A fimbrial proteins of Salmonella enteritidis in their abilities to elicit humeral immune response in hens. Bull. Vet. Ins. Pulawy., 47: 95-105.

Madadgar, O., H. Tadjbakhsh, T.Z. Salehi, M. Mahzounieh and M.M. Feizabadi, 2008. Evaluation of random amplified polymorphic DNA analysis and antibiotic susceptibility application in discrimination of Salmonella typhimurium isolates in Iran. New Microbiol., 31: 211-216.

Mirmomeni, M.H., S. Sisakhtnezhad and A. Sharifi, 2008. Rapid detection of Salmonella enteritidis by PCR amplification of the SefA gene and its cloning. Pak. J. Biol. Sci., 11: 428-432.

Murugkar, H.V., H. Rahman and P.K. Dutta, 2003. Distribution of virulence genes in Salmonella serovars isolated from man and animals. Indian J. Med. Res., 117: 66-70.

Naughton, P.J., G. Grant, M. Sojka, S. Bardocz, C.J. Thorns and A. Pusztai, 2001b. Survival and distribution of cell-free SEF 21 of Salmonella enterica serovar Enteritidis in the stomach and various compartments of the rat gastrointestinal tract in vivo. J. Med. Microbiol., 50: 1049-1054.

Naughton, P.J., G. Grant, S. Bardocz, E. Allen-Vercoe, M.J. Woodward and A. Pusztai, 2001 a. Expression of type 1 fimbriae (SEF 21) of Salmonella enterica serotype Enteritidis in the early colonisation of the rat intestine. J. Med. Microbiol., 50: 191-197.

Ochoa-Reparaz, J., B. Sesma, M. Alvarez, M.J. Renedo, J.M. Irache and C. Gamazo, 2004. Humoral immune response in hens naturally infected with Salmonella enteritidis against outer membrane proteins and other surface structural antigens. Vet. Res., 35: 291-298.

Oliveira, S.D., C.R. Roclenbuisch, M.C. Ce, S.L.S. Rocha and C.W. Canal, 2003. Evaluation of selective and non-selective enrichment PCR procedures for Salmonella detection. Lett. Applied Microbiol., 36: $217-221$.

Pan, T.M. and Y.J. Liu, 2002. Identification of Salmonella enteritidis isolates by polymerase chain reaction and multiplex polymerase chain reaction. J. Microbiol. Immunol. Infect., 35: 147-151.

Pasmans, F., A. Martel, F. Boyen, D. Vandekerchove and I. Wybo et al., 2005. Characterization of Salmonella isolates from captive lizard. Vet. Microbiol., 110: 285-291. 
Soumet, C., G. Ermel, N. Rose, V. Rose, P. Drouin, G. Salvat and P. Colin, 1999. Identification by a multiplex PCR-based assay of Salmonella typhimurium and Salmonella enteritidis strains from environmental swabs of poultry houses. Lett. Applied Microbiol., 29: 1-6.

Sukhnanand, S., S. Alcaine, L.D. Warnick, W.L. Su and J. Hof et al., 2005. DNA Sequence-based subtyping and evolutionary analysis of selected Salmonella enteric serotypes. J. Clin. Microbiol., 43: 3688-3698.
Thorns, C.J., C. Turcotte, C.G. Gemmell and M.J. Woodward, 1996. Studies into the role of the SEF14 fimbrial antigen in the pathogenesis of Salmonella enteritidis. Microbial Pathogen., 20: 235-246.

Van Asten, A.J.A.M. and J.E. van Dijk, 2005. Distribution of classic virulence factors among Salmonella sp. FEMS Immunol. Med. Microbiol., 44: 251-259. 